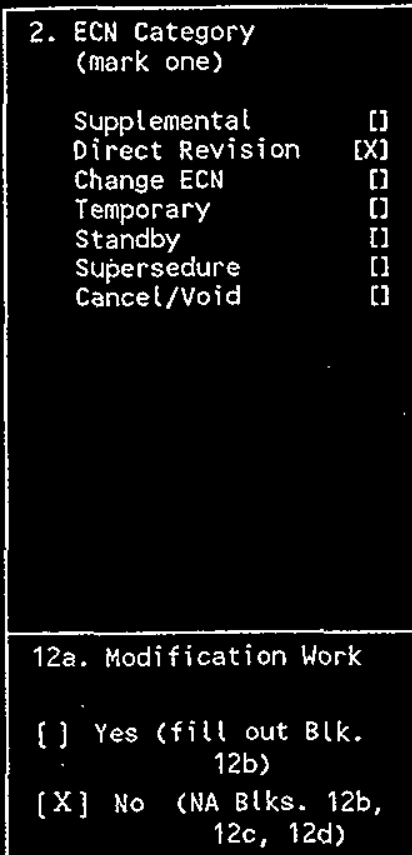

13a. Description of Change

Revision to meet SEL, Rev. 6 . $372-3739$ No.

$\mathrm{N} / \mathrm{A}$
3. Originator's Name, Organization, MSIN, and Telephone No.

Treah Nuxall, SNF CVD, R3-47,

6. Project Title/No./Work Order No.

Spent Nuclear Fuel Cold Vacuum Drying

9. Document Numbers Changed by this ECN (includes sheet no. and rev.) Alf Revo SNF-3876, SNF-3877, SNF-3878, SNF-3879, SNF3880 , SNF-3881, SNF-3882, SNF-3883, SNF-3884, SNF-3886, SNF-3887, SNF-3888, SNF-3890, SNF3891, SNF-3892, SNF-3893, SNF-3894, SNF-3895, SNF-3920, SNF-3921, SNF-3922, SNF-3923, SNF3924, SNF-3925, SNF-3926, SNF-3927, SNF-3928, SNF-3929, SNF-3930, SNF-3931, SNF-3932, SNF3933, SNF-3934, SNF-3935, SNF-3936

12b. Work Package $12 c$. Modification Work Complete

$\mathrm{N} / \mathrm{A}$

Design Authority/Cog. Engineer Signature \& Date

13b. Design Basel ine Document?
(X] No

12d. Restored to Original Condition (Temp. or Standby ECN only)

$$
\mathrm{N} / \mathrm{A}
$$

Design Authority/Cog. Engineer Signature \& Date

[ ] Yes [X] No

5. Date

$3 / 31 / 99$

8. Approval Designator $Q, S^{N}$

1. Related PO No. $\mathrm{N} / \mathrm{A}$

14a. Justification (mark one)

Criteria Change [X] Design Improvement [] Environmental As-Found [] Facilitate Const

Const. Error/Omission

14b. Justification Details

Revision to SEL.

15. Distribution (include namie, MSIN, and no. of copies)

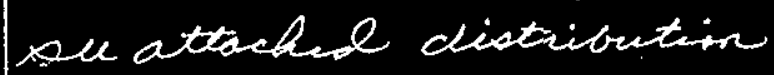




\section{ENGINEERING CHANGE NOTICE}

\section{Design \\ Verification Required}

[] Yes

[X] No
17. Cost Impact

ENGINEERING

$\begin{array}{lll}\text { Additional } & {[]} & \$ \\ \text { Savings } & {[1]} & \text { \$ }\end{array}$

\section{CONSTRUCTION}

18. Schedule Impact (days)

[ ] \$

[] $\$$
Improvement

Delay
[]

[]

19. Change Impact Review: Indicate the related documents (other than the engineering documents ident ified on side 1 ) that will be affected by the change described in Block 13 . Enter the affected document number in Block 20.

\section{SDD/DD}

Functional Design Criteria

Operating Specification

Criticality Specification

Conceptual Design Report

Equipment Spec.

Const. Spec.

Procurement Spec.

Vendor Information

OM Manual

FSAR/SAR

Safety Equipment List

Radiation Work Permit

Environmental Impact Statement

Environmental Report

Environmențal Permit
[]

[ ]

[]

[]

[]
[]

[]

[]

Tank Calibration Manual

Health Physics Procedure

Spares Multiple Unit Listing

Test Procedures/Specification

Component Index

ASME Coded ltem

Human Factor Consideration

Computer Software

Electric Circuit Schedule

ICRS Procedure

Process Control Manual/Plan

Process Flow Chart

Cell Arrangement Drawing

Essential Material Specification

Fac. Proc. Samp. Schedule

Purchase Requisition

Tickler File

Inventory Adjustment Request

20. Other Affected Documents: (NOTE: Documents listed below will not be revised by this ECN.) Signatures below indicate that the signing organization has been notified of other affected documents listed below.

Document Number/Revision

Document Number/Revision

Document Number Revision

$$
\text { N/A }
$$

21. Approvals

\section{Design Authority}

Designated Cog. Eng.

Author ized Rep. Mgr.

QA

other R. Wh.tehurst.

safuty(nuclear)

\section{signature}

c. Miska cR Mh

Date

c. Van Katwijk

T. Choho

T. D. Haysist (DA)

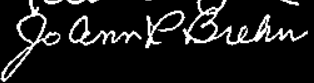

Signature

Date

Design Agent

PE

QA

Safety

Design

Environ.

Other

\section{DEPARTMENT OF ENERGY}

Signature or a Control Number that

tracks the Approval Signature

ADOI TIONAL

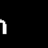




\title{
FIKE MCO PRESSURE SAFETY ELEMENT
}

\author{
Carl Van Katwijk \\ Numatec Hanford, Richland, WA 99352 \\ U.S. Department of Energy Contract DE-AC06-96RL13200 \\ EDT/ECN: 626879653776 \\ UC: 620 \\ Org Code: $2 \mathrm{G} 300$ \\ Charge Code: $105559 / \mathrm{A} 000$ \\ B\&R Code: 39EW40400 \\ Total Pages: $\perp>15$
}

Key Words: Fike MCO Pressure Safety Elcment

Abstract: Fike MCO Pressure Salcly Elcment

TRADEMARK DISCLAIMER. Reference herein to any specilic commercial product, process, or service hy trade name, trademark, manufacturer, or otherwise, does not necessarily constitute or imply its endorsement, recommendation, or favoring by the l /nited Stales Government or any agency thereof or its contractors or subcontractors.

Printed in the United States of America. To obtain copies of this document. cortact: Bocunent (ontrol Services. P. (). 130x 950). Mailstop H6-188, Richland WA 99352, Plone (509) 372-2420. 1\%ax (5019) 376-4989.

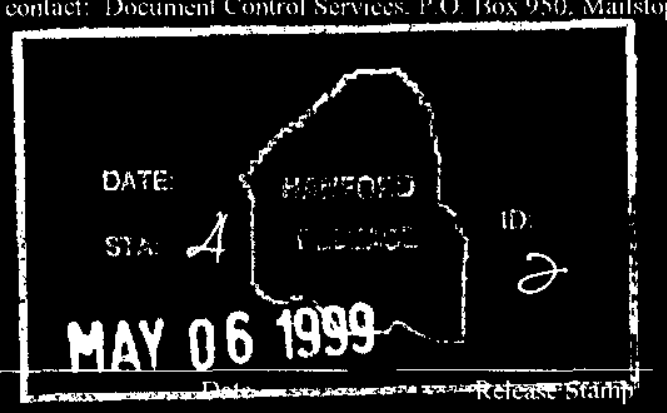

Approved for Public Release 


\section{RECORD OF REVISION}

Page 1

(2) Title

FIKE MCO PRESSURE SAFETY ELEMENT

Change Control Record

(3) Revision

(4) Description of Change - Replace, Add, and Delete Pages

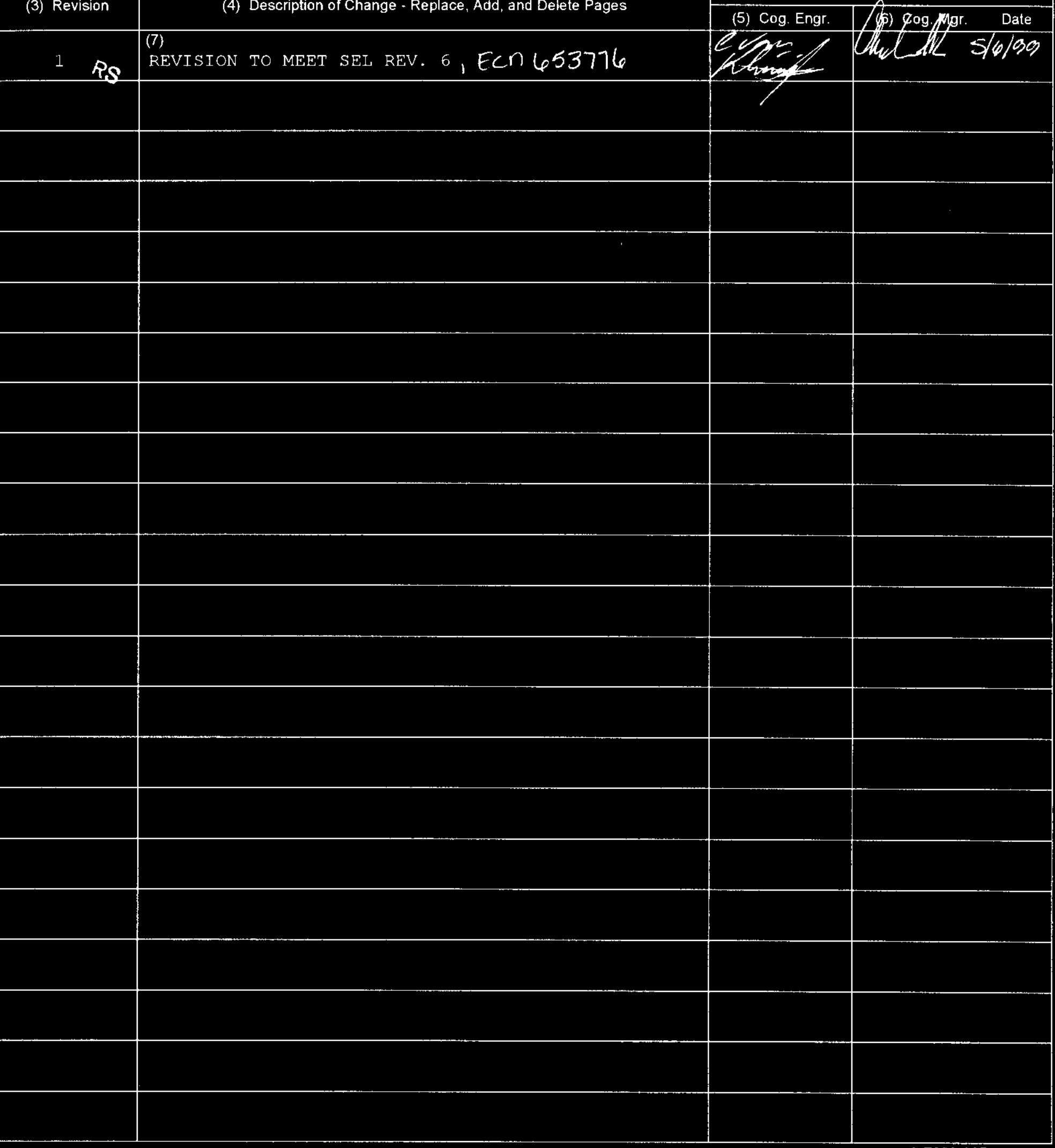


Commercial Grade Item Upgrade Dedication Form

ECN No. NA CGI No. CGI-SNE-D-07-P4-044

Title: FIKE MCO PRESSURE SAFETY ELEMENT

\begin{tabular}{|c|c|c|c|c|}
\hline 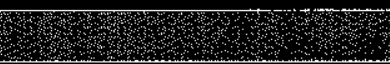 & Section 1 Par & information & & 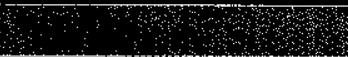 \\
\hline Item No: NA & Manufacturer: & & Supp & \\
\hline Mfg. Part/Model No.: & & Supplier's P/N: & & \\
\hline Part Description: & & & & \\
\hline End Use Description: & & & & \\
\hline 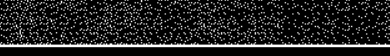 & - Section 2a Compo & ent Iniormation & & . \\
\hline $\begin{array}{l}\text { Equipment No.: VPS-PSE- } \\
\mathbf{1} \mathbf{3 3}\end{array}$ & $\begin{array}{l}\text { Specification No.: W-441- } \\
\text { P4, Rev. } 2\end{array}$ & Manufacturer: Fike & & Past P.O. No.: NA \\
\hline $\begin{array}{l}\text { Procurement and/or Model } \\
\text { No.: HOV-UT, } 1 " \text { ", } \\
316 S S / T E F / 316 S S \text {, } \\
\text { 30PSI, } 150^{\circ} \mathrm{C} \text {, } \\
\text { Standard MFG } \\
\text { Tolerances, FU-1", } \\
\text { 316SS }\end{array}$ & Equipment Supplier (if differer & from manufacturer): & TBD & $\begin{array}{l}\text { Equip. Supplier's Part No: } \\
\text { NA }\end{array}$ \\
\hline
\end{tabular}

Component Description: This pressure safety element is a 1 inch rupture disc used to prevent an overpressure condition in the MCO. The pressure safety element is located at the MCO and discharges to the plant vent.

1. Is the Item available from a catalogue of a qualified NQA1 supplier? (coordinate with project CGI interface Engineer or BTR)

[ ] YES (go to \#2 below)

[X] NO (go to procedure step 5.3.2, proceed to dedicate ltem.)

If not available from a qualified NQA1 supplier, is it available from an ISO 9000 supplier? (coordinate with project CGI interface Engineer or BTR)

[ ] YES (go to \#2 below, then go to procedure step 5.3.2, proceed to dedicate ltem)

[X] NO (go to procedure step 5.3.2, proceed to dedicate ltem.)

2. List of Candidate qualified suppliers or ISO 9000 suppliers

company name and type contact name phone

NA

3. Recommended Procurement Strategy (coordinate with project CGI interface Engineer or BTR):

NA

1. Question \#1: Is the ltem subject to design or specification requirements that are unique to nuclear facilities or activities?

[ ] YES (the ltem is not commercial grade)

$[\mathbf{X}] \quad$ NO (continue) 
2. Question \#2: Is the Item used in applications other than nuclear facilities or activities?

1 ] NO (the item is not commercial grade)

[X] YES (continue)

3. Question \#3: Is the Item ordered from manufacturer/supplier on the basis or specifications set forth in the Published product information (e.g., manufacturer's catalog)?

[ ] NO (the ltem is not commercial grade)

$[\mathbf{X}]$ YES (continue)

[X] All three criteria have been satisfied. The ltem meets the definition of commercial grade.

Section 2d Reason for Dedication

The abovo described liem is being Dedicaled for use in the application cited for the following reason(s):

\begin{tabular}{|c|c|}
\hline $\mathbf{x}]$ & $\begin{array}{l}\text { Item is being purchased from a non ESL manufacturer supplier as commercial grade to be used in a Safety Class } \\
\text { application. }\end{array}$ \\
\hline ] & $\begin{array}{l}\text { Item is being purchased from a non ESL manufacturer supplier as commercial grade to be used in a Safety Significant } \\
\text { application. }\end{array}$ \\
\hline 1 & $\begin{array}{l}\text { Item was purchased from a non ESL manufacturer supplier as commercial grade to be used in a Safety Class } \\
\text { application. }\end{array}$ \\
\hline 1 & $\begin{array}{l}\text { Item was purchased from a non ESL manufacturer supplier as commercial grade to be used in a Safety Significant } \\
\text { application. }\end{array}$ \\
\hline & Other ('like-for-like', similar, substitution, replacement evaluation) \\
\hline
\end{tabular}

A. Part/Component Safety Function:

1. Maintains pressure boundary, prevents helium leakage from MCO or airleakage into MCO during vacuum operation, $\mathrm{H} 2$ explosion.

2. Prevents MCO over pressure, prevents thermal runaway

3. Maintain critical function before and after seismic event.

B. Part/Component Functional Mode:

Safety Function \#1:

1 ] Active - Mechanical or Electrical change of state is required to occur for the component to perform its safety function

[ $\mathbf{X}$ ] Passive - Change of state is not required for the component to perform its safety function Safety Function \#2:

[X] Active - Mechanical or Electrical change of state is required to occur for the component to perform its safety function.

[ ] Passive - Change of state is not required for the component to perform its safety function Safety Function \#3:

[ ] Active -Mechanical or Electrical change of state is required to occur for the component to perform its safety function.

[X] Passive - Change of state is not required for the component to perform its safety function

C. Host Component Safety Function (if applicable): NA

1. 
D. Failure Mechanisms(s) and the effects on component or system safety function (see worksheet 1 );

1. Failure of the disc to rupture at its nominal burst pressure.

2. Fracture of the disc housing or piping attachment.

3. Disc ruptures or leaks at a lower pressure than its nominal burst pressure.

4. Upon actuation of rupture disc, pieces of disc separate and block downstream flow path and/or check valve.

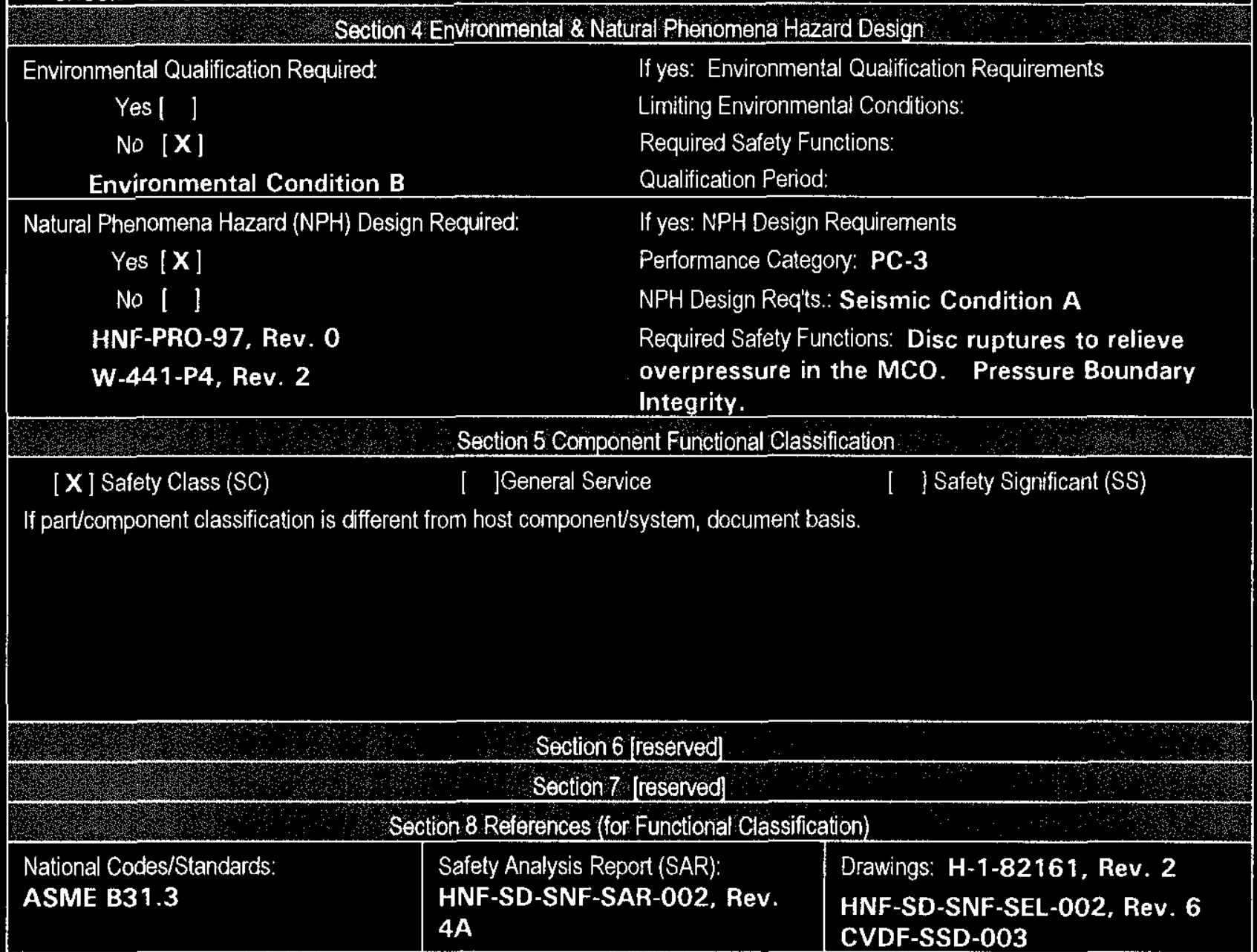

Vendor Manuals/Manufacturer/Supplier Information: Fike Rupture Disc Application, Selection, and Specification, HOV Series

Other: 
Commercial Grade Item Upgrade Dedication Form

ECN No. NA CGI No. CGI-SNF-D-07-P4-044

SNF-3936, Rev. I

Page 4 of 13

Section 9 Critical Characteristics

\begin{tabular}{|c|c|c|c|c|}
\hline \multicolumn{5}{|c|}{ 20 $10, \quad$ Section 9 Critical Characteristics } \\
\hline \begin{tabular}{l}
\multicolumn{1}{c}{ Critical Characteristics } \\
Verification Document:: Vendor \\
Specifications, \\
HNF-SD-SNF-SEL-002, Rev. 6
\end{tabular} & Acceptance Criteria/Tolerances & $\begin{array}{l}\text { Acceptance } \\
\text { Method }\end{array}$ & ID & Function \\
\hline \multicolumn{5}{|c|}{ 1. Item Identification Critical Characteristics (necessary for reasonable assurance that the Item delivered is the Item specified) } \\
\hline $\begin{array}{l}\text { Component Number-Procedure } \\
\text { and/or Model Number }\end{array}$ & $\begin{array}{l}\text { HOV-UT, 1", } \\
316 S S / T E F / 316 S S, 30 \text { PSI, } \\
150^{\circ} \mathrm{C}, \text { Standard MFG. } \\
\text { Tolerance, FU-1", 316SS, (Per } \\
\text { Procurement Package W-441- } \\
\text { P4, Rev. 2, Section H, Design } \\
\text { Data Sheet) }\end{array}$ & $1, \mathbf{I N}$ & $\mathbf{x}$ & \\
\hline Nameplate - Manufacturer & Fike & $1, \mathrm{IN}$ & $\mathbf{x}$ & \\
\hline Process Connection & 1 Inch Butt Weld & $1, \mathbf{I N}$ & $\mathbf{X}$ & \\
\hline \multicolumn{5}{|c|}{ 2. Physical Critical Characteristics (necessary for reasonable assurance that the Item delivered is the Item specified) } \\
\hline Material, Housing & Stainless Steel (Note 4) & 1, IN $1, T$ & $\mathbf{x}$ & \\
\hline Material, Process Connection & Stainless Steel (Note 4) & 1, IN $1, T$ & $x$ & \\
\hline Material, Rupture Disc & Teflon (Note 4) & 1, IN $1, T$ & $\mathrm{x}$ & \\
\hline \multicolumn{5}{|c|}{$\begin{array}{l}\text { 3. Performance Critical Characteristics (necessary \& sufficient for reasonable assurance that the Item will perform its intended } \\
\text { safety function(s)) }\end{array}$} \\
\hline Pressure Boundary Integrity & $\begin{array}{l}\text { No leakage at test pressure of } \\
165 \text { psig. Note } 3 \text {. }\end{array}$ & $1, T$ & & $x$ \\
\hline Internal Pressure & 150 psig and Full Vacuum & $1, T$ & & $\underline{x}$ \\
\hline Leakage Past Rupture Disc & $\begin{array}{l}\text { Pressure Test to } 15 \mathrm{psig} \text {, } \\
\text { leakage to bubble tight } \\
\text { standards }<10-3 \mathrm{ml} / \mathrm{sec} \\
\text { Note } 5\end{array}$ & $1, T$ & & $x$ \\
\hline Rupture Disc Burst Pressure & $\begin{array}{l}\text { Nominal } 30 \text { psig (Not to exceed } \\
31 \text { psig). }\end{array}$ & $1, T$ & & $x$ \\
\hline Inspect Disc after Rupture & $\begin{array}{l}\text { No loose pieces from ruptured } \\
\text { disc. }\end{array}$ & $1, \mathrm{~T}$ & & $x$ \\
\hline Environmental & Note 1 & & & \\
\hline Seismic Condition A & Note 2 & $1, T$ & & $\mathbf{x}$ \\
\hline
\end{tabular}




\begin{tabular}{|c|c|}
\hline Commercial Grade Item Upgrade Dedication Form & SNF-3936, Rev. ! \\
\hline $\begin{array}{l}\text { ECN No. NA CGI No. CGI-SNF-D-07-P4-1044 } \\
\text { Title: FIKE MCO PRESSURE SAFETY ELEMENT }\end{array}$ & lage 5 of 13 \\
\hline $\begin{array}{l}\text { 4. Notes and Legend: } \\
\text { 1. The pressure safety element and rupture disc are not } \\
\text { subject to degradation at environmental conditions of } 40^{\circ} \mathrm{F} \\
\text { and } 60 \% \mathrm{RH} \text { or } 11^{\circ} \mathrm{F} \text { and } 22 \% \mathrm{RH} \text { and are suitable for } \\
\text { Condition B application. } \\
\text { 2. Maintain critical function before and after Seismic event. W- } \\
441-\mathrm{P} 4-\mathrm{Rev} .2 \text {, Appendix L, page L-20 provides a seismic } \\
\text { testing plan for this safety class, Seismic Condition A } \\
\text { component at a Seismic Specta TBD. Equipment that has } \\
\text { been shaker-table tested should not be installed in a plant } \\
\text { (Ref. IEEE Standard } 344-1984 \text {, Section } 7 \text { ). Consequently, the } \\
\text { seismic test constitutes a destructive test. The industry } \\
\text { sampling practice for destructive test is to test only one item. } \\
\text { 3. Pressure test housing at } 110 \% \text { of design accident condition } \\
\text { pressure of } 150 \text { psig. The rupture disc burst pressure is } \\
30 \text { psig, nominal. The rupture disc must be removed and a } \\
\text { blank installed for this test. } \\
\text { 4. Material verification acceptance method may be by either } \\
\text { inspection or test. } \\
\text { 5. During test - do not wet rupture disc (with wetting solution, } \\
\text { e.g. Snoop type soap solution). }\end{array}$ & $\begin{array}{l}\text { Acceptance Method: } \\
\text { 1. Special Test and Inspection } \\
1 \text {,IN for Inspection } \\
1, T \text { for Test } \\
\text { 2. Commercial Grade Survey } \\
\text { 3. Source Verification } \\
\text { 4. Vendor/ltem History }\end{array}$ \\
\hline 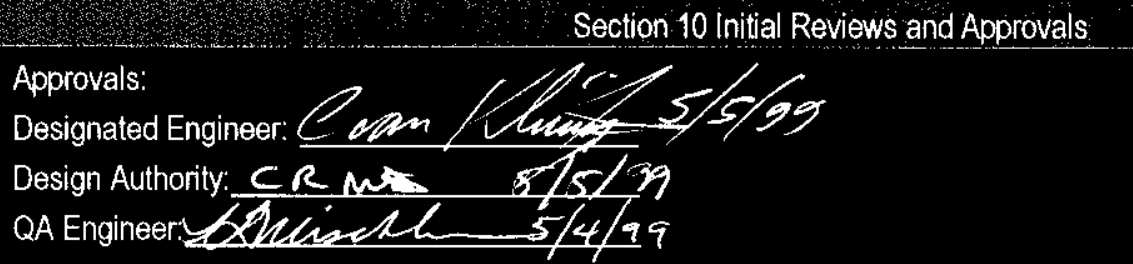 & \\
\hline
\end{tabular}




Commercial Grade Item Upgrade Dedication Form
\begin{tabular}{|l|l|}
\cline { 2 - 2 } ECN No. NA & SNF-3936, Rev. $\mathbf{1}$ \\
Title: FIKE MCO PRESSURE SAFETY ELEMENT & Page 6 of 13 \\
\hline
\end{tabular}

\begin{tabular}{|c|c|c|}
\hline \multicolumn{3}{|c|}{$\begin{array}{c}\text { WORKSHEET } 1 \\
\text { DETERMINATION OF FAILURE MECHANISMSMODES }\end{array}$} \\
\hline \multicolumn{3}{|c|}{ SECTION 1} \\
\hline $\begin{array}{l}\text { Typical Failure } \\
\text { Mechanisms }\end{array}$ & Definition & $\begin{array}{l}\text { Applicable to Component } \\
\text { under Evaluation }\end{array}$ \\
\hline Fracture & $\begin{array}{l}\text { Separation of a solid accompanied by little or no } \\
\text { macroscopic plastic deformation. }\end{array}$ & $\begin{array}{l}\text { Yes [ ] No [X]; If Yes, indicate failure } \\
\text { Mode. }\end{array}$ \\
\hline Corrosion & $\begin{array}{l}\text { The gradual deterioration of a material due to } \\
\text { chemical or electrochemical reactions, such as } \\
\text { oxidation, between the material and its environment. }\end{array}$ & $\begin{array}{l}\text { Yes [ ] No [X]; If Yes, indicate failure } \\
\text { Mode. }\end{array}$ \\
\hline Erosion & $\begin{array}{l}\text { Destruction of materials by the abrasive action of } \\
\text { moving fluids, usually accelerated by the presence } \\
\text { of solid particles carried with the fluid. }\end{array}$ & $\begin{array}{l}\text { Yes [ ] No [X]; If Yes, indicate failure } \\
\text { Mode. }\end{array}$ \\
\hline Open Circuit & $\begin{array}{l}\text { An electrical circuit that is unintentionally broken so } \\
\text { that there is no complete path for current flow. }\end{array}$ & $\begin{array}{l}\text { Yes [ ] No [X]; If Yes, indicate failure } \\
\text { Mode. }\end{array}$ \\
\hline Short Circuit & $\begin{array}{l}\text { An abnormal connection by which an electrical } \\
\text { current is connected to ground, or to some }\end{array}$ & $\begin{array}{l}\text { Yes [ ] No [X ]; If Yes, indicate failure } \\
\text { Mode. }\end{array}$ \\
\hline Blockage & $\begin{array}{l}\text { Clogging of a filtering medium resulting in the } \\
\text { inability to perform its purification function or } \\
\text { blockage of flow. }\end{array}$ & $\begin{array}{l}\text { Yes [ ] No [X]; If Yes, indicate failure } \\
\text { Mode. }\end{array}$ \\
\hline Seizure & $\begin{array}{l}\text { Binding of a normally moving item through excessive } \\
\text { pressure, temperature, friction, jamming. }\end{array}$ & $\begin{array}{l}\text { Yes [ ] No [X]; If Yes, indicate failure } \\
\text { Mode. }\end{array}$ \\
\hline Unacceptable Vibration & $\begin{array}{l}\text { Mechanical oscillations produced are beyond the } \\
\text { defined permissible limits due to unbalancing, poor } \\
\text { support, or rotation at critical speeds. }\end{array}$ & $\begin{array}{l}\text { Yes [ ] No [X]; If Yes, indicate failure } \\
\text { Mode. }\end{array}$ \\
\hline Loss of Properties & $\begin{array}{l}\text { A loss of mechanical and physical properties of a } \\
\text { material due to exposure to high temperatures, } \\
\text { radiation exposure. }\end{array}$ & $\begin{array}{l}\text { Yes [] No [X]; If Yes, indicate failure } \\
\text { Mode. }\end{array}$ \\
\hline Excess Strain & $\begin{array}{l}\text { Under the action of excessive extemal forces the } \\
\text { material of the part has been deformed or distorted. }\end{array}$ & $\begin{array}{l}\text { Yes [ ] No [X]; If Yes, indicate failure } \\
\text { Mode. }\end{array}$ \\
\hline Mechanical Creep & $\begin{array}{l}\text { From prolonged exposure to high temperature and } \\
\text { stress, the object will show a slow change in its } \\
\text { physical (shape and dimension) and mechanical } \\
\text { characteristics. }\end{array}$ & $\begin{array}{l}\text { Yes [ ] No [X]; if Yes, indicate failure } \\
\text { Mode. }\end{array}$ \\
\hline Ductile Fracture & $\begin{array}{l}\text { Fracture characterized by tearing of metal } \\
\text { accompanied by appreciable gross plastic } \\
\text { deformation. }\end{array}$ & $\begin{array}{l}\text { Yes [ ] No [X]; If Yes, indicate failure } \\
\text { Mode. }\end{array}$ \\
\hline & Additional Failure Modes Applicable to the Com & t Undar Evaluation \\
\hline 1. Failure of the & rupture at its nominal burst pressure. & \\
\hline 2. Fracture of the & ousing or piping attachment. & \\
\hline 3. Disc ruptures a & ver pressure than its nominal burst pres & \\
\hline 4. Disk ruptures at & pressure and fragments potentially bloc & ownstream equipment. \\
\hline Lea & isc in disc holder. & \\
\hline
\end{tabular}


Commercial Grade Item Upgrade Dedication Form

ECN No. NA CGI No. CGI-SNF-D-(07-P4-044
Title: FIKE MCO PRESSURE SAFETY ELEMENT

CHECKLIST 1

ACCEPTANCE METHOD 1

SPECIAL TEST/INSPECTION VERIFICATION

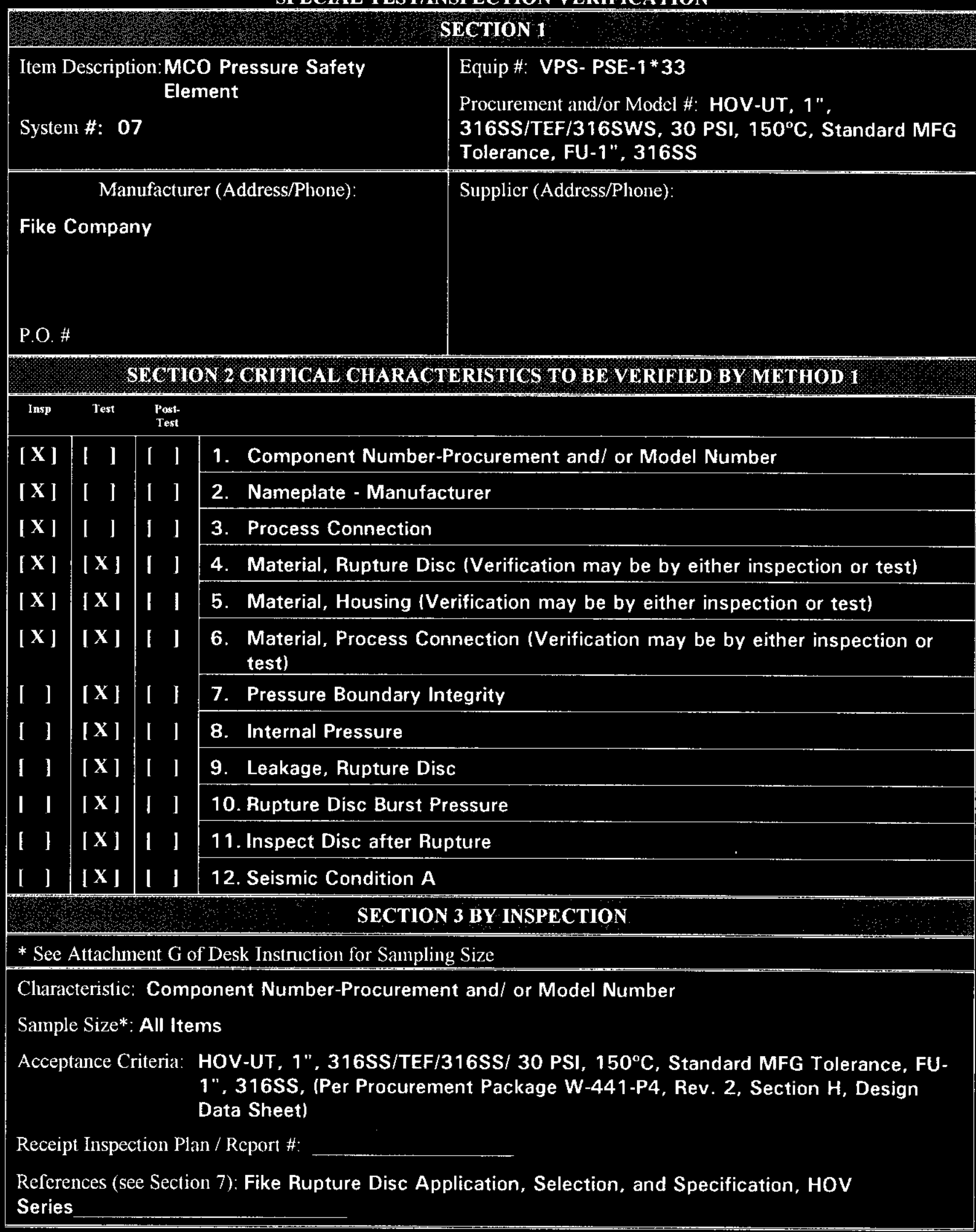


Characteristic: Nameplate - Manufacturer

Sample Size*: All Items

Acceptance Criteria: Fike

Receipt Inspection Plan / Report \#:

References (see Section 7):

Characteristic: Process Connection

Sample Size*: All Items

Acceptance Criteria: 1 Inch Butt Weld

Receipt Inspection Plan / Report \#:

References (see Section 7):

Characteristic: : Material, Housing

Sample Size*: *: Normal Sampling Size

Acceptance Criteria: Stainless Steel

Receipt Inspection Plan / Report \#:

References (see Section 7):

Characteristic: Material, Process Connection

Sample Size*: *: Normal Sampling Size

Acceptance Criteria: Stainless Steel

Receipt Inspection Plan / Report \#:

References (see Section 7):

Characteristic: Material, Rupture Disc

Sample Size*: *: This is a destructive test since the disc may suffer damage during test for testing. Utilize the disc that has been ruptured for the burst pressure test to test the material. Test only one item.

Acceptance Criteria: Teflon

Receipt Inspection Plan / Report \#:

References (see Section 7): 
Commercial Grade Item Upgrade Dedication Form

ECN No. NA CGI No. CGI-SNF-D-07-P4-044

SNF-3936, Rev. 1

Page 9 of 13

\section{SECTION 4 BY SPECIAL TEST}

* See Attachment G of Desk Instruction for Sampling Sizc

\begin{tabular}{|l|l}
\hline Test To Be Performed by: & Number of ltems to be Tested:
\end{tabular}

I J Purchaser

[ ] Supplier/Manufacturer**

Test/Inspection Location:

I ] Other

Characteristic for Tcst: Pressure Boundary Integrity

Acceptance Criteria: No Leakage at Process Test Pressure of 165 psig

Sample Size*: Normal Sampling Size

Actual Test Value:

Test Plan and Report \#: References (sec Section 7):

Characteristic for Test: Internal Pressure

Acceptance Criteria: 150 psig and full vacuum

Sample Size*: Normal Sampling Size

Actual Test Value:

Tesı Plan and Report \#:

References (see Section 7):

Characteristic for Test: Leakage Past Rupture Disc

Acceptance Criteria: At $15 \mathrm{psig}$, leakage to bubble type standards $<10-3 \mathrm{ml} / \mathrm{sec}$ (do not wet disc with liquid solution, e.g. Snoop).

Sample Size*: Normal Sampling Size

Actual Tesi Value:

Test Plan and Report \#: References (sec Section 7):

Characteristic for Test: Rupture Disc Burst Pressure

Acceptance Criteria: Nominal 30 psig (not to exceed 31 psig).

Sample Size*: Destructively Test Only One Item. After burst, use this disc for material test.

Actual Test Value:

Test Plan and Report \#: References (see Section 7):

Characteristic for Test: Inspect Disc after Rupture

Acceptance Criteria: No loose pieces from ruptured disc.

Sample Size*: Destructively test only one item. Examining the disc used for the burst pressure test. Actual Test Value:

Test Plan and Report \#: References (see Section 7): 
F.CN No. NA CGI No. CGI-SNF-D-07-P4-(1)44

Title: FIKE MCO PRESSURE SAFETY ELEMENT

Characteristic for Test: Seismic Condition A

Acceptance Criteria: Maintain Critical Function Before and After Seismic Event

Sample Size*: Destructively Test Only One Item

Actual Test Value:

Test Plan and Reporl \#: References (see Section 7):

**If Supplier/Manufacturer or Oher, Refer to CGI Checklist-2 for Support Information 


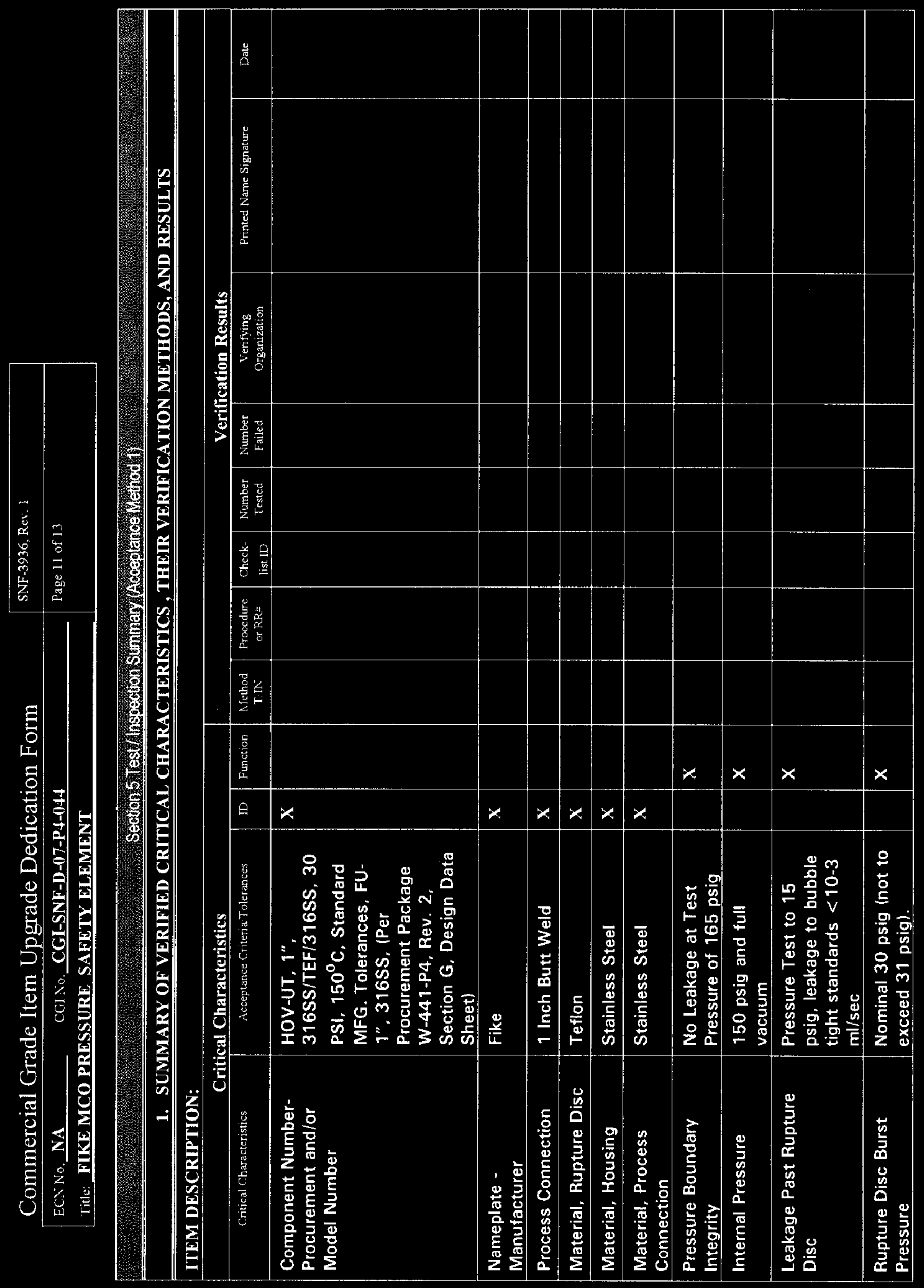




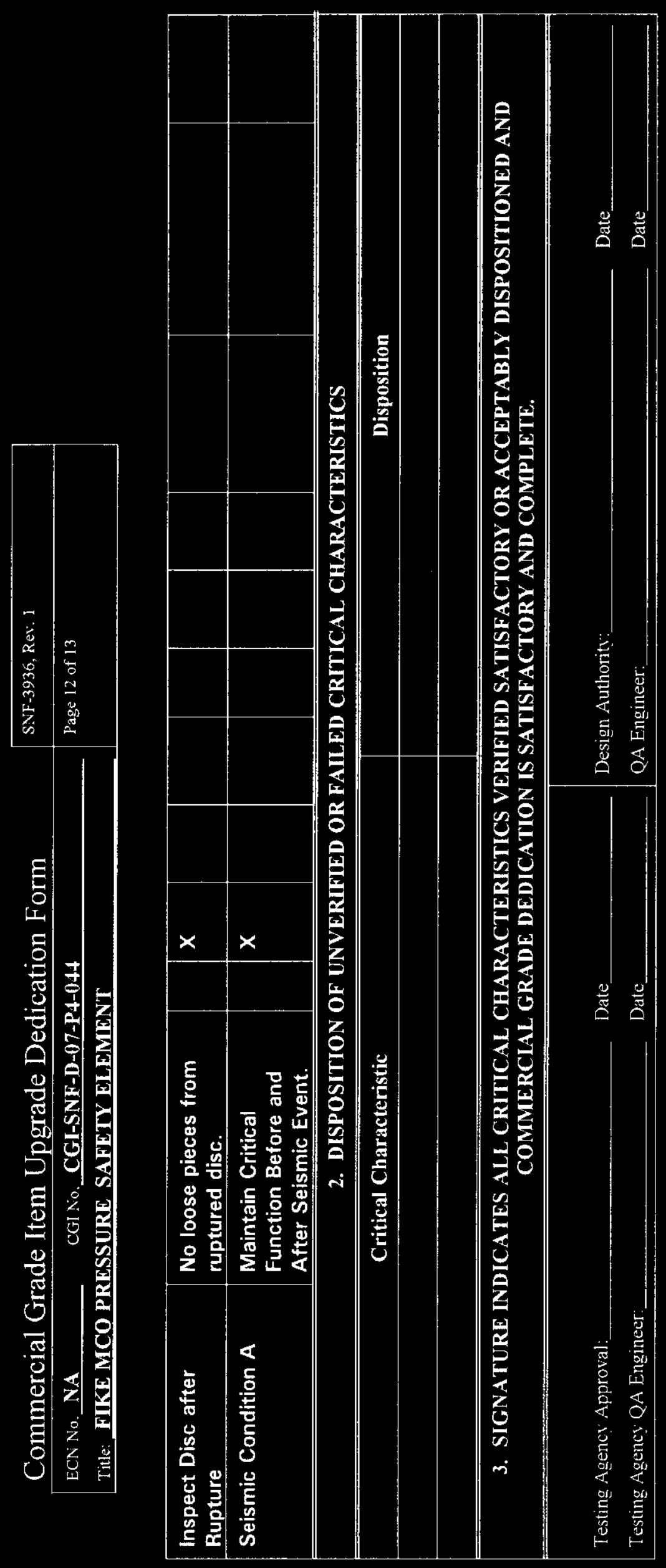




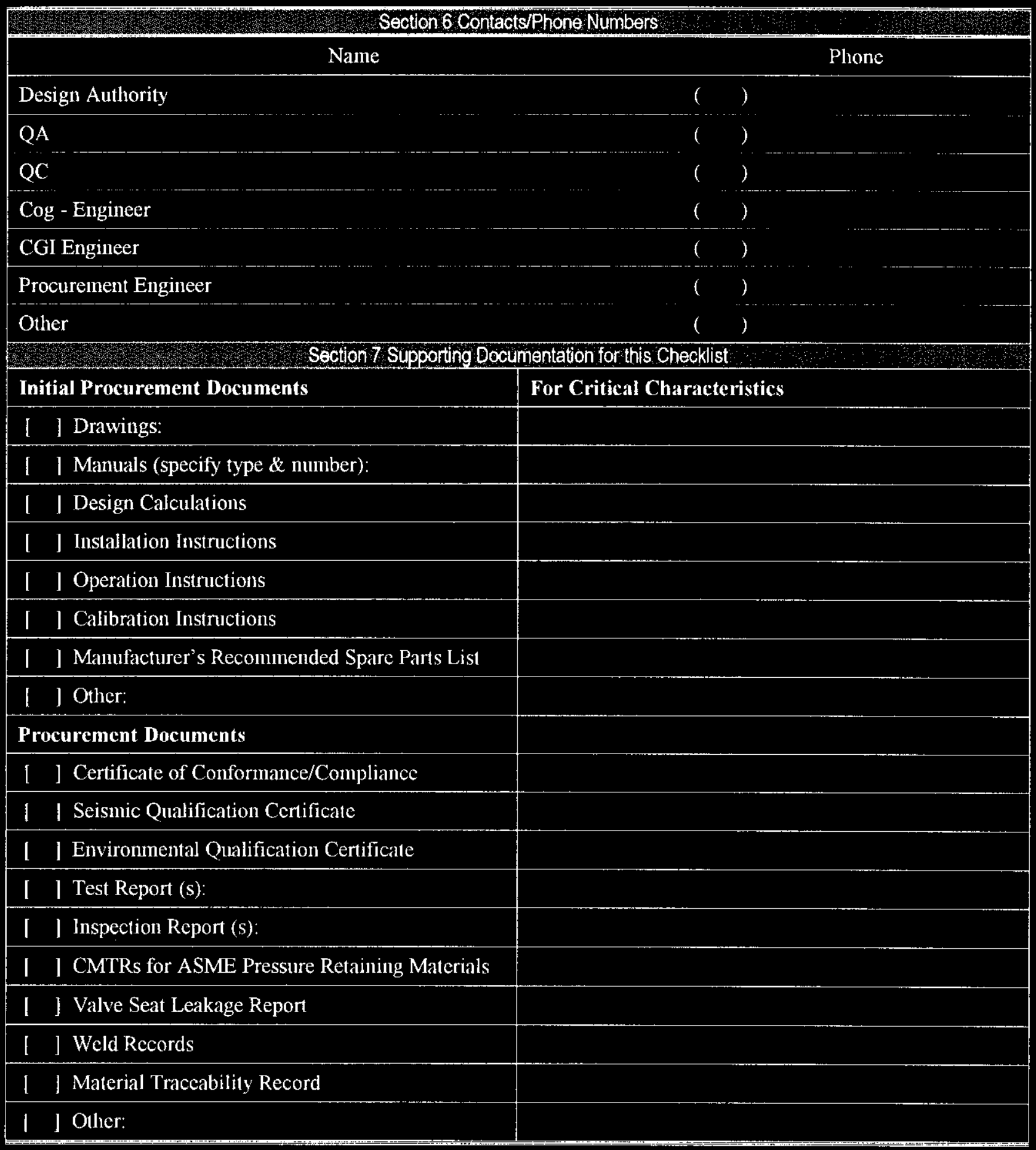

